\title{
Free Amino Acid Contents of Horse Red Cells in Relation to AR and BA Systems: Analysis by Highspeed Liquid Chromatography with Li-type Column
}

Kei Hanzawa and Seiki Watanabe

Tokyo University of Agriculture, Setagaya-ku 156

(Received August 19, 1991)

\begin{abstract}
Free amino acids in horse red cells were analyzed in detail by using the Li-type column. The influence of AR (arginase activity -high and-low) and BA (basic amino acid-negative and positive) systems on free amino acid concentration and composition was also investigated. The horse red cells contained 23 kinds of amino acids and 1 dipeptide, i.e. $o$-phosposerine, taurine, asparagine, citrulline, $\beta$-amino-isobutyrate, $\gamma$-aminobutyrate, 1 -methyl-histidine, carnosine ( $\beta$-alanylhistidine), ornithine and protein-constituting amino acids which had been detected by the Na-type column analysis.

$\mathrm{BA}^{+}$cells showed significantly higher concentrations of aspartate, threonine, serine, alanine, tyrosine, histidine and lysine than $\mathrm{BA}^{-}$cells $(\mathrm{P}<0.05)$ regardless of $\mathrm{AR}$ types, which had no significant effects on the concentration of these amino acids $(P<0.3)$. Both ornithine and arginine concentrations were significantly different in every combination of four types of horse red cells $(\mathrm{P}<0.05)$ and their ranking for ornithine concentration was $\left[\mathrm{AR} \cdot \mathrm{H}: \mathrm{BA}^{+}\right]>\left[\mathrm{AR} \cdot \mathrm{H}: \mathrm{BA}^{-}\right]>\left[\mathrm{AR} \cdot \mathrm{L}: \mathrm{BA}^{+}\right]>\left[\mathrm{AR} \cdot \mathrm{L}: \mathrm{BA} \mathrm{C}^{-}\right]$; in contrast, that for arginine concentration was $\left[\mathrm{AR} \cdot \mathrm{L}: \mathrm{BA}^{+}\right]>\left[\mathrm{AR} \cdot \mathrm{L}: \mathrm{BA}^{-}\right]>\left[\mathrm{AR} \cdot \mathrm{H}: \mathrm{BA}^{+-}\right]>[\mathrm{AR} \cdot \mathrm{H}:$ $\left.\mathrm{BA}^{-}\right]$.
\end{abstract}

Anim. Sci. Technol. (Jpn.) 63 (3) : 249-255, 1992

Key words : AR system, BA system, free amino acid, horse red cell

WATANABE and coworkers presented a classification of horse red cells by conbining arginase (EC 3. 5. 3. 1) activity -high (ARGase H, AR $\cdot \mathrm{H}$ ) and -low (ARGase L, AR - L) types $(\mathrm{AR} \text { system })^{8)}$ and basic amino acid -negative $\left(\mathrm{BA}^{-}\right)$and -positive $\left(\mathrm{BA}^{+}\right)$types (BA system) ${ }^{21}$. Furthermore, free amino acid contents in horse red cells have been shown to be controlled by both $\mathrm{AR}$ and BA systems which are located in different autosomes ${ }^{6,7,22)}$. AR $\cdot \mathrm{H}$ cells contain relatively high concentration of ornithine and low concentration of arginine as compared with $\mathrm{AR} \cdot \mathrm{L}$ cells ${ }^{9)}$. On the other hand, $\mathrm{BA}^{+}$ cells have higher contents of some basic and neutral amino acids than those of $\mathrm{BA}^{-}$cells ${ }^{9,21)}$. These findings are based on the measurement by liquid chromatography using the $\mathrm{Na}$-type column ${ }^{9,21}$.

In the present paper, free amino acid concentrations in horse red cells were analyzed in detail by means of highspeed liquid chromatography using the Li-type column which has a higher separation capacity for amino acids than the Na-type column. And a more detailed analysis was done regarding the influence of $\mathrm{AR}$ and BA systems on free amino acid composition and concentration in horse red cells. 


\section{Hanzawa and Watanabe}

\section{Materials and Methods}

Blood sample collection and treatment:

Heparinized blood samples were taken from male thoroughbred horses aged $5 \sim 10$ years by means of jugular venepuncture, then were immediately chilled at $4^{\circ} \mathrm{C}$ and washed three times with an ice-cold $154 \mathrm{mM} \mathrm{NaCl}$. The plasma and buffy coat were discarded and packed cells were obtained after centrifugation at $1450 \times \mathrm{g}(3000 \mathrm{rpm})$ for $10 \mathrm{~min}$. Some packed cells were frozen at $-20^{\circ} \mathrm{C}$ and were used for measuring arginase activity for one month ${ }^{19)}$. The other red cell-parts were deproteinized with trichloroacetic acid for analyzing free amino acid concentrations ${ }^{8,21}$.

Classification by $A R$ and $B A$ systems: Horse red cells were classified into four types with $A R$ and $B A$ systems, namely, [AR $\left.\cdot H: B A^{-}\right]$, $\left[\mathrm{AR} \cdot \mathrm{H}: \mathrm{BA}^{+}\right],\left[\mathrm{AR} \cdot \mathrm{L}: \mathrm{BA}^{-}\right]$and $[\mathrm{AR} \cdot \mathrm{L}$ : $\left.\mathrm{BA}^{+}\right]$types ${ }^{8-10,21}$.

Free amino acids assay: From each of the four red cell types, six samples were randomly selected and deproteinized for free amino acid analysis. The free amino acid concentrations were determined by the amino acid analytical system based on liquid chromatography with fluorescent reaction by $o$-phthalaldehyde (Model LC-6 A of Shimadzu Co., Ltd., Kyoto, Japan). The chromatography was performed with an ISC-07/S 1504 Li-type analytical column (size $15 \mathrm{~cm} \times 4 \mathrm{~mm}$ I.D.) and a guard column (size $5 \mathrm{~cm} \times 4 \mathrm{~mm}$ I.D.). The analytical condition of the equipment was determined in accordance with an accessory text.

Statistical treatment for analytical values:

The differences in free amino acid concentrations among four cell-types were statistically analyzed by SCOOT and KNOTT's cluster analysis $^{4,11)}$. Pattern similarity ${ }^{13)}$ was used as an indicator for the comparison of free amino acid composition among the cell-types. Pattern similarity $S(A, B)$ between pattern $A\left(a_{1}\right.$, $\left.a_{2}, \ldots, a_{n}\right)$ and $B\left(b_{1}, b_{2}, \ldots, b_{n}\right)$ was calculated as a cosine of angle $(\theta)$ between vector $\overrightarrow{\mathrm{OA}}$ and vector $\overrightarrow{\mathrm{OB}}$ in $n$ dimensional space.

\section{Results}

In this experiment, trace (a limit of measurement) indicated the presence of an amino acid at $1 \mathrm{nmol} / \mathrm{ml}$ of packed red cells. Analysis was performed for 32 kinds of amino acids and 2 kinds of dipeptides. Horse red cells always contained 23 kinds of free amino acids and 1 dipeptide : i.e. 14 kinds of protein-constituting amio acids ${ }^{21)}$, and $o$-phosposerine, taurine, asparagine, citlulline, $\beta$-alanine, $\beta$-amino-isobutyrate, $\gamma$-amino-butyrate, 1 -methylhistidine, ornithine and carnosine ( $\beta$-alanylhistidine). Sarcosine, $\alpha$-aminoadipic acid and anserine $(\beta-$ alanyl-1-methylhistidine) were observed in several samples. One of $\left[\mathrm{AR} \cdot \mathrm{H}: \mathrm{BA}^{+}\right]$cells especially showed high concentrations of anserine $(38.8 \mathrm{nmol} / \mathrm{m} l)$ and carnosine $(23.9 \mathrm{nmol} /$ $\mathrm{m} l$ ). Concentrations of these amino acids in other cells were less than $1 \mathrm{nmol} / \mathrm{m} l$ and $3.50 \pm 0.52 \mathrm{nmol} / \mathrm{m} l$, respectively. In contrast, hydroxyproline, $a$-amino-n-butyrate, metionine, cystine, cystathione, 3-methylhistidine, hydroxylysine and 2,4-diamino- $n$-butyrate were not detected in horse red cells. All horse red cells contained glutamine, proline and $\gamma$ glutamyl-cysteinyl-glycine (GSH), but their concentrations were not measured in this experiment.

Table 1 shows free amino acid concentrations in four types of horse red cells. No significant influence of the AR system was observed for free amino acid concentrations, except for those of ornithine and arginine ${ }^{9)}$. A significant difference was seen in the concentration of ornithine and arginine in every combination of the four types of cells $(P<0.05)$ and their ranking for ornithine concentration was $[\mathrm{AR} \cdot \mathrm{H}$ : $\left.\mathrm{BA}^{+}\right]>\left[\mathrm{AR} \cdot \mathrm{BA}^{-}\right]>\left[\mathrm{AR} \cdot \mathrm{L}: \mathrm{BA}^{+}\right]>[\mathrm{AR} \cdot \mathrm{L}:$ $\left.\mathrm{BA}^{-}\right]$. In contrast, the ranking for arginine concentration was $\left[\mathrm{AR} \cdot \mathrm{L}: \mathrm{BA}^{+}\right]>[\mathrm{AR} \cdot \mathrm{L}$ : $\left.\mathrm{H}: \mathrm{BA}^{-}\right]>\left[\mathrm{AR} \cdot \mathrm{H}: \mathrm{BA}^{+}\right]>\left[\mathrm{AR} \cdot \mathrm{H}: \mathrm{BA}^{-}\right]$. Two types of cells, $\left[\mathrm{AR} \cdot \mathrm{H}: \mathrm{BA}^{+}\right]$and $[\mathrm{AR} \cdot \mathrm{L}$ : $\left.\mathrm{BA}^{+}\right]$contained significantly higher concen- 
Horse Red Cell Free Amino Acids

Table 1. Concentrations of free amino acids in four types of thoroughbred horse red cells classified with $\mathrm{AR}$ and $\mathrm{BA}$ systems

\begin{tabular}{|c|c|c|c|c|c|}
\hline \multicolumn{2}{|c|}{ Amino acids $\backslash$ Cell-type } & \multirow{2}{*}{$\frac{\left[\mathrm{AR} \cdot \mathrm{H}: \mathrm{BA}^{-}\right]}{53.6 \pm 1.2^{\mathrm{a}}}$} & \multirow{2}{*}{$\frac{\left[\mathrm{AR} \cdot \mathrm{H}: \mathrm{BA}^{+}\right]}{39.8 \pm 1.3^{\mathrm{a}}}$} & \multirow{2}{*}{$\frac{\left[\mathrm{AR} \cdot \mathrm{L}: \mathrm{BA}^{-}\right]}{47.9 \pm 1.8^{\mathrm{a}}}$} & \multirow{2}{*}{$\frac{\left[\mathrm{AK} \cdot \mathrm{L}: \mathrm{BA}^{+}\right]}{43.6 \pm 1.7^{\mathrm{a}}}$} \\
\hline o- phosphoserine & (Pser) & & & & \\
\hline Taurine & (Tau) & $39.8 \pm 1.4^{\mathrm{a}}$ & $34.7 \pm 1.6^{\mathrm{a}}$ & $26.3 \pm 0.81^{\mathrm{a}}$ & $37.2 \pm 1.7^{\mathrm{a}}$ \\
\hline Aspartate & $(A s p)$ & $46 \pm 6.5^{b}$ & $93 \pm 12^{\mathrm{a}}$ & $36.3 \pm 3.1^{b}$ & $178 \pm 13^{\mathrm{a}}$ \\
\hline Threonine & $(\mathrm{Th} r)$ & $251 \pm 7.0^{b}$ & $625 \pm 7.0^{\mathrm{a}}$ & $170 \pm 4.7^{b}$ & $813 \pm 17^{\mathrm{a}}$ \\
\hline Serine & (Ser) & $234 \pm 7.9^{b}$ & $562 \pm 7.4^{\mathrm{a}}$ & $141.2 \pm 3.3^{b}$ & $213 \pm 9.4^{\mathrm{a}}$ \\
\hline Asparagine & $(A s n)$ & $83.2 \pm 2.5^{\mathrm{a}}$ & $41.8 \pm 4.2^{\mathrm{a}}$ & $36.3 \pm 3.6^{3}$ & $110 \pm 24^{a}$ \\
\hline Glutamate & (Glu) & $66.1 \pm 2.7^{\mathrm{a}}$ & $56.2 \pm 3.4^{\mathrm{a}}$ & $52.5 \pm 2.7^{\mathrm{a}}$ & $76.0 \pm 1.3^{a}$ \\
\hline Glycine & (Gly) & $372 \pm 8.0^{\mathrm{a}}$ & $275 \pm 5.5^{\mathrm{a}}$ & $302 \pm 8.6^{a}$ & $398 \pm 12^{\mathbf{a}}$ \\
\hline Alanine & (Ala) & $234 \pm 6.2^{b}$ & $618 \pm 7.2^{\mathrm{a}}$ & $135 \pm 5.5^{b}$ & $813 \pm 20^{a}$ \\
\hline Citrulline & (Cit) & $37.2 \pm 1.7^{\mathrm{a}}$ & $30.9 \pm 1.8^{\mathrm{a}}$ & $38.0 \pm 1.0^{\mathrm{a}}$ & $47.9 \pm 2.9^{\mathrm{a}}$ \\
\hline Valine & (Val) & $204 \pm 5.2^{\mathrm{a}}$ & $170 \pm 4.5^{\mathrm{a}}$ & $14.1 .2 \pm 3.0^{\mathrm{a}}$ & $204.2 \pm 3.0^{\mathrm{a}}$ \\
\hline Isoleucine & (Ile) & $35.5 \pm 1.0^{\mathrm{a}}$ & $30.2 \pm 1.7^{\mathrm{a}}$ & $34.7 \pm 1.1^{3}$ & $42.4 \pm 0.63^{\mathrm{a}}$ \\
\hline Leucine & (Leu) & $117.5 \pm 3.5^{\mathrm{a}}$ & $102.3 \pm 3.2^{\mathrm{a}}$ & $112.2 \pm 2.5^{\mathrm{a}}$ & $125.9 \pm 1.8^{\mathrm{a}}$ \\
\hline Tyrosine & (Tyr) & $229 \pm 6.9^{b}$ & $347 \pm 6.2^{\mathrm{a}}$ & $144 \pm 4.5^{\mathrm{b}}$ & $446 \pm 4.7^{\mathrm{a}}$ \\
\hline Phenylalanine & (Phe) & $43.6 \pm 1.7^{\mathrm{a}}$ & $38.9 \pm 1.4^{\mathrm{a}}$ & $42.8 \pm 0.96^{\mathrm{a}}$ & $47.8 \pm 0.57^{\mathrm{a}}$ \\
\hline$\beta$-Alanine & $(\beta-\mathrm{Ala})$ & $5.2 \pm 0.44^{\mathrm{a}}$ & $3.5 \pm 0.62^{b}$ & $3.8 \pm 0.35^{b}$ & $6.4 \pm 0.43^{\mathrm{a}}$ \\
\hline b-Amino-iso-butyrate & $(\beta-\mathrm{Aib})$ & $3.9 \pm 0.47^{2}$ & $3.0 \pm 0.45^{2}$ & $2.7 \pm 0.61^{\mathrm{a}}$ & $4.4 \pm 0.86^{\mathrm{a}}$ \\
\hline$r$-Aminobutyrate & $(\gamma-A b a)$ & $3.2 \pm 0.27^{\mathrm{a}}$ & $4.4 \pm 0.65^{a}$ & $3.4 \pm 0.12^{\mathrm{a}}$ & $3.3+0.51^{a}$ \\
\hline Histidine & (His) & $188 \pm 7.5^{b}$ & $369 \pm 7.2^{\mathrm{a}}$ & $190 \pm 4.6^{b}$ & $447 \pm 12^{\mathrm{a}}$ \\
\hline 1-Methylhistidine & $(1 \mathrm{MeH}$ is $)$ & $11.2 \pm 0.70^{\mathrm{a}}$ & $8.5 \pm 0.57^{\mathrm{a}}$ & $10.0 \pm 0.73^{\mathrm{a}}$ & $12.9 \pm 0.82^{\mathrm{a}}$ \\
\hline Carnosine & (Car) & $3.4 \pm 0.32^{\mathrm{a}}$ & $4.1 \pm 1.2^{\mathrm{a}}$ & $3.0 \pm 0.17^{\mathrm{a}}$ & $3.7 \pm 0.49^{\mathrm{a}}$ \\
\hline Ornithine & (Orn) & $851 \pm 27^{b}$ & $2138 \pm 27^{\mathrm{a}}$ & $74.1 \pm 1.2^{\mathrm{d}}$ & $114.8 \pm 2.4^{c}$ \\
\hline Lysine & (Lys) & $602 \pm 18^{b}$ & $4470 \pm 50^{\mathrm{a}}$ & $417 \pm 14^{b}$ & $5250 \pm 69^{a}$ \\
\hline Arginine & (Arg) & $81 \pm 4.3^{d}$ & $132 \pm 12^{\mathrm{c}}$ & $724 \pm 21^{b}$ & $2099 \pm 21^{a}$ \\
\hline
\end{tabular}

Remarks : 1) Mean \pm S. E. (nM/ml packed cells) based on 6 samples for each cell-type.

2) As for comparisons among cell-types, the values with different superscripts are significantly different $a>b>c>d,(P<0.05)$.

trations of aspartate, threonine, serine, alanine, tyrosine, histidine and lysine (7084 \pm 97 and $8660 \pm 145 \mathrm{nM} / \mathrm{m} l$, respectively) than the other two types of cells, $\left[\mathrm{AR} \cdot \mathrm{H}: \mathrm{BA}^{-}\right]$and $\left[\mathrm{AR} \cdot \mathrm{L}: \mathrm{BA}^{-}\right] \quad(1784 \pm 60$ and $1233 \pm 40 \mathrm{nmol} /$ $\mathrm{m} l$, respectively, $\mathrm{P}<0.05)^{21)}$. Concentrations of o-phosphoserine, taurine, asparagine, glutamate, glycine, citlulline, valine, isoleucine, leucine, phenylalanine, $\beta$-alanine, $\beta$-aminoiso-butyrate, $\gamma$-aminobutyrate, 1 -methylhistidine and carnosine did not differ significantly among four red cell-types $(P>0.50)$. Total concentrations of those amino acid for $[A R$. $\left.\mathrm{H}: \mathrm{BA}^{-}\right],\left[\mathrm{AR} \cdot \mathrm{H}: \mathrm{BA}^{+}\right],\left[\mathrm{AR} \cdot \mathrm{L}: \mathrm{BA}^{-}\right]$and $\left[\mathrm{AR} \cdot \mathrm{L}: \mathrm{BA}^{+}\right]$cells were $1079 \pm 31,843 \pm 32$,
$857 \pm 28$ and $1164 \pm 53 \mathrm{nmol} / \mathrm{ml}$, respectivel.

Pattern similarities of free amino acids among four types of red cells were calculated and the results are shown in table 2. Relatively low values were observed for the 23 kinds of amino acids and 1 dipeptide (group t) $(0.532 \sim$ 0.827 ). Relatively high values were seen in every combination $(0.989 \sim 0.998)$ for group a amino acids, for which no significant difference in the concentration was observed among the four cell types. Pattern similarities for ornithine and arginine (group b) were very high when combined with the same AR types (0.999) and extremely low when combined with different AR types (below 0.2). On the contrary, 
Table 2. Comparison in pattern similarity of free amino acid compositions among four types of thoroughbred horse red cells classified with $\mathrm{AR}$ and BA systems

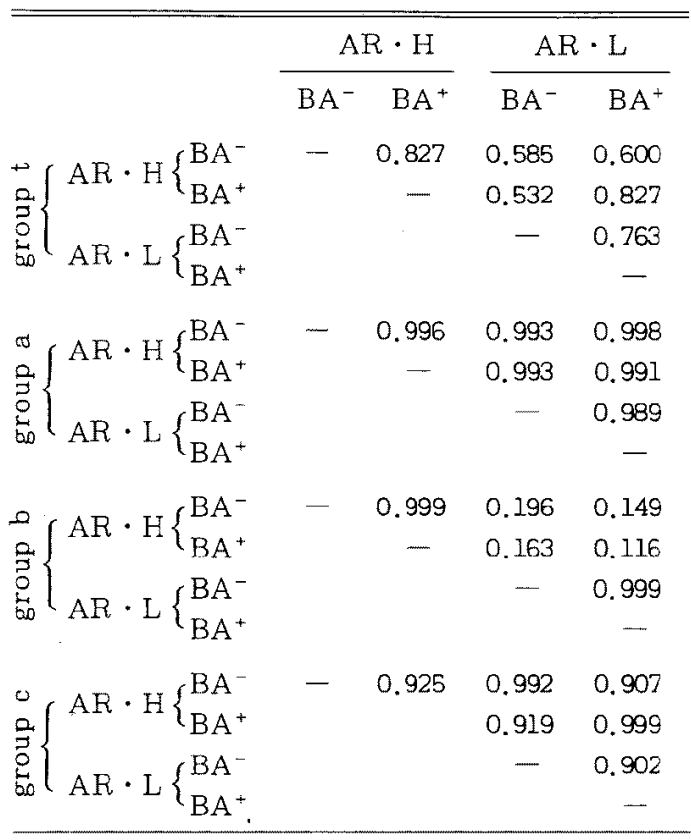

Remarks : Pattern similarities of amino acid in each group were calculated by follows: group t; Pser, Tau, Asp, Thr, Ser, Asn, Glu, Gly, Ala, Cit, Val, Ile, Leu, Tyr, Phe, $\beta$-Ala, $\beta$-Aib, $r$-Aba, His, 1 MeHis, Car, Orn, Lys and Arg.

group a: Pser, Tau, Asn, Glu, Gly, Cit, Val, Ile, Leu, Phe, $\beta$-Ala, $\beta$-Aib, $\gamma$-Aba, $1 \mathrm{MeHis}$ and Car.

group b; Orn and $\Lambda \mathrm{rg}$ group c; Asp, Thr, Ser, Ala, Tyr, His and Lys.

An abbr. of amino acid name is shown in table 1.

the value was higher when combined with the same BA types (above 0.99) than when combined with different $B A$ types $(0.902 \sim 0.925)$ for group c amino acids, for which a significant difference was observed in their concentrations between $\mathrm{BA}^{+}$and $\mathrm{BA}^{-}$cells.

\section{Discussion}

The above results suggest that the $\mathrm{AR}$ and
BA systems modulate concentrations of amino acids in horse red cells, namely, the AR system regulates ornithine and arginine, and the $\mathrm{BA}$ system is concerned with aspartate, threonine, serine, alanine, tyrosine, histidine, ornithine, lysine and arginine. Similar results were obtained in the previous analysis based on the measurement by liquid chromatography using the Na-type column ${ }^{9}$. These findings suggest the following; (1) AR and BA systems have no direct effects on the concentration of amino acids other than those mentioned above, and (2) horse red cells have at least 7 kinds of amino acids and 1 kind of dipeptide (carnosine) in addition to protein-constituting amino acids. A sample showed an extremely high concentration of carnosine and its methylated derivative (anserine), suggesting the presence of individual variation in the activity of synthetic enzyme for these peptides, carnosine synthętase (EC 6.3.2.11) and carnosine Nmethyltransferase (EC 2. 1. 1. 22).

Free amino acid concentrations in horse red cells estimated by the Na-type column analysis $^{9)}$ showed similar values to those estimated by the Li-type column analysis, except glutamate, methionine, ornithine and arginine. Glutamate concentration measured by the $\mathrm{Li}^{-}$ type column analysis $(62.7 \pm 5.0 \mathrm{nmol} / \mathrm{ml})$ showed a half value compared with that estimated by the Na-type column analysis $\left.(111.9 \pm 2.8 \mathrm{nmol} / \mathrm{ml})^{9}\right)$. The reason for this is that glutamate and glutamine are separately measured in the Li-type column analysis. Methionine had been detected by the Na-type column analysis $(19.3 \pm 2.8 \mathrm{nmol} / \mathrm{ml})^{9}$, but was not detected by the Li-type column analysis (less than $1 \mathrm{nmol} / \mathrm{ml}$ ). This result suggests the possibility that the peak which had been regarded as methione in the $\mathrm{Na}$-type column analysis was another substance. Ornithine concentrations of $\left[\mathrm{AR} \cdot \mathrm{H}: \mathrm{BA}^{-}\right]$and $[\mathrm{AR}$. $\left.\mathrm{H}: \mathrm{BA}^{+}\right]$cells, and arginine concentrations of $\left[\mathrm{AR} \cdot \mathrm{L}: \mathrm{BA}^{-}\right]$and $\left[\mathrm{AR} \cdot \mathrm{L}: \mathrm{BA}^{+}\right]$cells determined by the Li-type column analysis were 
higher than those determined by the Na-type column ${ }^{9}$. This result suggests that analysis by the the Li-type column was more effective in separating basic amino acids. Concentration of ornithine plus arginine in red cells with the same BA types showed similar values regardless of AR types. This phenomenon is very important for research regarding the relation between arginase activity and concentrations of ornithine and arginine.

Arginase in red cells from human, crabeating monkey (Macaca fascicularis), rat (the Wistar strain), sheep and horse has been found to cause high levels of intracellular ornithine and low levels of arginine, since arginine is hydrolyzed to ornithine by this enzyme $^{1,2,8,9,12,14,15\rangle}$. Inherited deficiencies of the amino acids transport system in the membrane of sheep and horse red cells are associated with elevated concentrations of intracellular free amino acids ${ }^{2,5,15,20)}$. Two types of cells, [AR . $\left.\mathrm{H}: \mathrm{BA}^{+}\right]$or $\left[\mathrm{AR} \cdot \mathrm{L}: \mathrm{BA}^{+}\right]$, showed high concentrations of aspartate, threonine, serine, alanine, tyrosine, histidine, lysine and ornithine or arginine as compared with $\left[\mathrm{AR} \cdot \mathrm{H}: \mathrm{BA}^{-}\right]$or $\left[\mathrm{AR} \cdot \mathrm{L}: \mathrm{BA}^{-}\right]$cells. A possibility may be suggested that the amino acid transport activities of cell membrane are lower in $[\mathrm{AR} \cdot \mathrm{H}$ : $\left.\mathrm{BA}^{+}\right]$and $\left[\mathrm{AR} \cdot \mathrm{L}: \mathrm{BA}^{+}\right]$cells than in $[\mathrm{AR}$. $\left.\mathrm{H}: \mathrm{BA}^{-}\right]$and $\left[\mathrm{AR} \cdot \mathrm{L}: \mathrm{BA}^{-}\right] \mathrm{cells}^{3,5,20)}$. [AR . $\left.\mathrm{H}: \mathrm{BA}^{+}\right]$cells had higher concentrations of ornithine than the other three cell-types, and $\left[\mathrm{AR} \cdot \mathrm{L}: \mathrm{BA}^{+}\right]$cells had higher concentrations of arginine than the other three cell-types ${ }^{2,93}$. These results suggest that $\left[\mathrm{AR} \cdot \mathrm{H}: \mathrm{BA}^{+}\right]$cells accumulate ornithine synthesized from arginine by the catalysis of arginase, and $\left[\mathrm{AR} \cdot \mathrm{L}: \mathrm{BA}^{+}\right]$ cells accumulate arginine in place of ornithine. The red cell amino acid transporter may provide a main route of transport for the intracellular free amino acid $3,5,17,18,20)$, and also participate in the efflux of free amino acids resulting from protein degradation during reticulocyte maturation ${ }^{16)}$.

\section{References}

1) Adriaenssens, K., D. Karcher, B. MaresCaU, C. Van Broeckhoven, A. Lowenthal and C. Terheggen, Hyperargininemia: the rat as a model for the human disease and the comparative response to enzyme replacement therapy with free arginase and arginase-loaded erythrocytes in vivo. Int. J. Biochem., 16 : 779-786. 1984.

2) Fincham, D.A., D.K. MASON and J.D. YounG, Red cell amino acid transport and arginase. Two new blood group markers in horses. Anim. Blood Groups Biochem. Genet., 16 (Suppl. 1) : 37-38. 1985.

3) Fincham, D.A., D.K. MAson and J.D. Younc, Characterization of a novel $\mathrm{Na}^{+}-$ independent amino acid transporter in horse erythrocytes. Biochem. J., 227: 1320. 1985.

4) Gates, C.E. and J.D. Bilbro, Illustration of a cluster analysis separation. Agronomy, J., 70: 462-465. 1978.

5) Hanzawa, K. and S. Watanabe, Physiogenetical studies of free amino acid variations in horse red blood cells. Anim. Gene., 20 (Suppl. 1) : 64-65. 1989.

6) Hanzawa, $\mathrm{K}$. and S. Watanabe, The genetic relationship between ARGase system and BA system in horse red cells. Jour. Agri. Sci., Tokyo Nogyo Daigaku, 35 : 206-212. 1991.

7) Hanazawa, K., S. Watanabe, M. Yokohama, S. KITOH and K. Mogi, The inheritance of ARGase types in horse erythrocytes. Jpn. J. Zootech. Sci., 58: 342-346. 1987.

8) Hanzawa, K., S. Watanabe, M. Yokohama and K. MoGr, The variation of arginase activities in horse erythrocytes. Jpn. J. Zootech. Sci., 57 : 356-359. 1986.

9) Hanzawa, K., S. Watanabe, M. Yokohama and K. MoGI, Relation between ARGase type and BA system of free amino acid type and concentrations of arginine and ornithine in horse erythrocytes. Jpn. J. Zootech. Sci., 57 : 758-764. 1986.

10) Mori, $M$. and M. Tachibana, Arginase in Experimental Methods in Biochemistry. vol. 11. (The Jpa. Biochem. Sco., eds.) 555-559. Tokyokagakudohzin. Tokyo. 1976.

11) ScooT, A.J. and M. KNoTT, A cluster analysis method for grouping analysis of 
variance. Biometrics., $30:$ 507-512. 1974.

12) Shih, V.E., T.C. Jones, H.L. Levy and P.M. Madigan, Arginase deficiency in Macaca fascicularis. I Arginase activity and arginine concentration in erythrocytes and in liver. Pediat. Res., 6 : 548-551. 1972.

13) Tamura, S. and F. Osawa, Amino acid pattern similarity between foods in Japan. Nutr. and Food., 22 : 494-496. 1969.

14) Terheggen, H.G., F. Lavinha, J.P. Colombo, M. Van Sande and A. Lowenthal, Familial hyper argininemia. J. Genet. hum., 20: 69-84. 1972.

15) TuCKER, E.M., P.C. Wright and J.D. Young, Influence of arginase deficiency on amino acid concentrations in sheep erythrocytes with a normal and with a defective transport system for amino acids. J. Physiol., 271 : 47-48. 1977.

16) TUCKER, E.M. and J.D. YounG, Biochemical changes during reticulocyte maturation in culture. Biochem.J., 192: 33-39. 1980.

17) YounG, J.D. and J.C. Ellory, Substrate specificity of amino acid transport in sheep erythrocytes. Biochem. J., 162: 3338. 1977 .

18) Young, J.D., J.C. Ellory and E.M. TUCKER, Amino acid transport in normal and glutathione-deficient sheep erythrocytes. Biochem. J., 154: 43-48. 1976.

19) Young, J.D. and P.C. Wright, A simple spot-test for the detection of erythrocyte arginase deficiency. Clin Chim. Acta., 79 : 611-613. 1977.

20) Watanabe, S. and K. Hanzawa, Relation between variations of free amino acid quantity by incubation and BA system in horse red blood cells. Jpn. J. Zootech. Sci., 55 : 591-593. 1984.

21) Watanabe, S., K. Hanzawa, S. Kanda, M. YokohaMA and K. MOGI, Variation of free amino acid concentration in red blood cells of horse. Jpn. J. Zootech. Sci., 55 : 307-314. 1984.

22) Watanabe, S., K. Hanzawa, M. YokoHAMA, N. KaWASAKI and K. Mogr, The inheritance mode of free amino acid type in horse red blood cells. Jpn. J. Zootech. Sci., 56 : 199-203. 1985. 


\section{馬赤血球中の遊離アミノ酸組成に対する $\mathrm{AR}$ および $\mathrm{BA}$ \\ システムの影響 : 高速液体クロマトグラフィー \\ ( $\mathrm{Li}$ 型力ラム) による分析}

\section{半澤 恵・渡邊誠喜}

東京農業大学, 東京都世间谷区 156

サラブレッド種馬の赤血球中の遊離アミノ酸組成を Li 型カラムにより分析し, 遊離アミ/酸組成と BA システム拈よび ARGase（AR）システムとの関係を調査した. 馬赤血球は 23 種類のアミノ酸並 びに 1 種類のペプチド, 即ちo-Phosphoserine, Taurine, Aspartate, Threonine, Serine, Asparagine, Glutamate, Glycine, Alanine, Citlulline, Valine, lsoleucine, Leucine, Tyrosine, Phenylalanine, $\beta$-Alanine, $\beta$-Amino-iso-butyrate, $\gamma$-Amino-butyrate, Histidine, 1-Methylhistidine, Carnosine ( $\beta$-alanylhistidine), Ornithine, Lysine および Arginine を含有していた.

$\mathrm{BA}^{+}$型の馬赤血球中の Aspartate, Threonine, Serine, Alanine, Tyrosine, Histidine おょび Lysine の濃度は $\mathrm{BA}^{-}$型のそれらに比へて有意に高濃度であった。 $\mathrm{AR} \cdot \mathrm{H}$ 型の馬赤血球は $\mathrm{AR} \cdot \mathrm{L}$ 型のそれに比べて Ornithine 濃度が高く，Arginine 濃度が低かった．AR システムとBA システム により分類された 4 種類の馬赤血球では $\left[\mathrm{AR} \cdot \mathrm{H}: \mathrm{BA}^{+}\right]$型の Ornithnie 濃度 $(2138 \pm 27 \mathrm{nmol} / \mathrm{ml})$ は $\left[\mathrm{AR} \cdot \mathrm{H}: \mathrm{BA}^{-}\right]$型のそれ $(851 \pm 27 \mathrm{nmol} / \mathrm{m} l)$ に比べて有意に高濃度であり，また， $[\mathrm{AR} \cdot \mathrm{L}$ ： $\left.\mathrm{BA}^{+}\right]$型の Argnine 濃度 $(2099 \pm 21 \mathrm{nmol} / \mathrm{ml})$ は $\left[\mathrm{AR} \cdot \mathrm{L}: \mathrm{BA}^{-}\right]$型のそれ $(724 \pm 21 \mathrm{nmol} / \mathrm{ml})$ に比べて有意に高濃度であった。

日畜会報， $63(3) ： 249-255 ， 1992$ 